Article

\title{
Fingerprinting, Antimicrobial, Antioxidant, Anticancer, Cyclooxygenase and Metabolic Enzymes Inhibitory Characteristic Evaluations of Stachys viticina Boiss. Essential Oil
}

\author{
Nidal Jaradat ${ }^{1, *}\left(\mathbb{D}\right.$ and Nawaf Al-Maharik ${ }^{2, *}$ \\ 1 Department of Pharmacy, Faculty of Medicine and Health Sciences, An-Najah National University, Nablus, \\ 00970, Palestine \\ 2 Department of Chemistry, Faculty of Science, An-Najah National University, Nablus, 00970, Palestine \\ * Correspondence: nidaljaradat@najah.edu (N.J.); na10@st-andrews.ac.uk (N.A.-M.)
}

Received: 20 August 2019; Accepted: 19 October 2019; Published: 28 October 2019

\begin{abstract}
The present study aimed to identify the chemical constituents and to assess the in-vitro, antimicrobial, anticancer, antioxidant, metabolic enzymes and cyclooxygenase (COX) inhibitory properties of essential oil (EO) of Stachys viticina Boiss. leaves. The S. viticina EO was isolated and identified using microwave-ultrasonic and GC-MS techniques, respectively. Fifty-two compounds were identified, of which endo-borneol was the major component, followed by eucalyptol and epizonarene. The EO was evaluated against a panel of in-vitro bioassays. The EO displayed antimicrobial activity against methicillin-resistant Staphylococcus aureus (MRSA), Escherichia coli and Epidermophyton floccosum, with MIC values of $0.039,0.078$ and $0.78 \mathrm{mg} / \mathrm{mL}$, respectively. The EO exhibited cytotoxicity against HeLa (cervical adenocarcinoma) and Colo-205 (colon) cancer cell lines with percentages of inhibition of $95 \%$ and $90 \%$, for EO concentrations of 1.25 and $0.5 \mathrm{mg} / \mathrm{mL}$, respectively. Furthermore, it showed metabolic enzyme ( $\alpha$-amylase, $\alpha$-glucosidase, and lipase) inhibitory $\left(\mathrm{IC}_{50}=45.22 \pm 1.1,63.09 \pm 0.26,501.18 \pm 0.38 \mu \mathrm{g} / \mathrm{mL}\right.$, respectively) and antioxidant activity, with an $\mathrm{IC}_{50}$ value of $19.95 \pm 2.08 \mu \mathrm{g} / \mathrm{mL}$. Moreover, the S. viticina EO showed high cyclooxygenase inhibitory activity against COX-1 and COX-2 with $\mathrm{IC}_{50}$ values of 0.25 and $0.5 \mu \mathrm{g} / \mathrm{mL}$, respectively, similar to those of the positive control (the NSAID etodolac). Outcomes amassed from this investigation illustrate that $S$. viticina EO represents a rich source of pharmacologically active molecules which can be further validated and explored clinically for its therapeutic potential and for the development and design of new natural therapeutic preparations.
\end{abstract}

Keywords: Stachys viticina; essential oil; cytotoxicity; antioxidant; antimicrobial; metabolic enzymes; cyclooxygenase

\section{Introduction}

People since ancient times have been using plant secondary metabolites in their daily life for the treatment of a wide range of diseases, as food preservatives and flavoring, and to annihilate insects. The World Health Organization has estimated that around $80 \%$ of the world population rely on plant extracts for their medication [1]. With time, synthetic chemicals have replaced plant secondary metabolites as the former provide early results. However, most synthetic drugs have various side effects and may cause many serious human health problems, therefore strategies have been implemented to replace synthetic drugs with plant secondary metabolites due to their ability to protect human body against oxidative damage and their great positive impact on human health [1-3]. Nowadays, due to the growing public awareness about the probable harmful effects of synthetic additives and the 
tendency of consumers to use natural foods, the use of natural bioactive compounds is witnessing significant growth [4]. Due to the wide prevalence of cancer worldwide, there is an essential and urgent need for a search for new anticancer medications [5]. In fact, majorities of used antitumor drugs are derived from natural sources [6].

The essential oils extracted from plants have been used in traditional medicine for the treatment and prevention of various diseases, in cosmetics, foods, and food supplements in addition to dental practice and hygiene products $[7,8]$.

Stachys (Lamiaceae family) is a large genus of herbs and shrubs containing around 300 species, widely spread in the temperate regions, especially in the Irano-Turanian and Mediterranean areas. Recently, several studies have documented anti-inflammatory, cytotoxic, antioxidant, immune system booster and antimicrobial properties of the extracts from a number of Stachys species [9].

Stachys viticina Boiss. is a perennial herbaceous shrubby plant that can reach a height of $100 \mathrm{~cm}$, with multiple branches, grey-colored and erect stems. The upper leaves are crenate, while the lower ones are large, oblong-ovate and verticillaster. In traditional medicine, various Stachys species have been utilized as anti-inflammatory, antimicrobial, anti-diarrheal, wound healing and astringent remedies. In addition, they were used to treat ulcers, cough, sclerosis of the spleen and genital tumors [10,11].

It is worth mentioning that the chemical constituents of $S$. viticina $\mathrm{EO}$, as well as its biological and pharmacological properties, haven't been reported. Thus, the current study was designed to investigate the chemical composition of the EO extracted from S. viticina leaves. Additionally, the antioxidant, anticancer, antimicrobial, metabolic enzyme ( $\alpha$-amylase, $\alpha$-glucosidase, and lipase) and cyclooxygenase (COX) inhibitory properties of $S$. viticina EO was assessed.

\section{Results}

\subsection{Phytochemical Composition of S. viticina Essential Oil}

In accord with our ability and experience in the isolation and identification of natural products from plants, as well as in assessing their biological activities, we decided to study the chemical components of $S$. viticina $\mathrm{EO}$, as well as their biological effects, in the hope to finding new drug leads from natural sources. The isolation procedure was carried out using a microwave-ultrasonic apparatus. The phytochemical composition was identified and estimated using GC-MS. The obtained yield of the EO was $1.72 \pm 0.97 \%$. GC-MS analyses indicated the presence of 52 phytochemical compounds in $S$. viticina $\mathrm{EO}$, of which endo-borneol was the major component, followed by eucalyptol and epizonarene, as revealed in Table 1 and Figure S1.

\subsection{Antioxidant and Metabolic Enzymes Inhibitory Activity}

The inhibitory activity of $S$. viticina EO against oxidation and metabolic enzymes ( $\alpha$-amylase and $\alpha$-glucosidase and lipase) was assessed using standard biomedical assays. The results showed that $S$. viticina essential oil has $\alpha$-amylase and $\alpha$-glucosidase inhibitory activities, with $\mathrm{IC}_{50}$ values of $45.22 \pm$ 1.1 and $63.09 \pm 0.26 \mu \mathrm{g} / \mathrm{mL}$, respectively.

As indicated in Table 2 and Figures S2-S5, the EO displayed antioxidant and antilipase activities with $\mathrm{IC}_{50}$ values of $19.95 \pm 2.08$ and $501.18 \pm 0.38 \mu \mathrm{g} / \mathrm{mL}$, respectively. 
Table 1. S. viticina leaves EO phytochemical composition.

\begin{tabular}{|c|c|c|c|c|}
\hline & Essential Oil Components & R.T. & R.I. & $\%, \pm \mathrm{SD}$ \\
\hline 1. & 2,4-Dimethyltetrahydro-2H-thiopyran 1,1-dioxide & 5.664 & 770 & $0.11 \pm 0.023$ \\
\hline 2. & $\alpha$-Phellandrene & 8.335 & 917 & $0.09 \pm 0.001$ \\
\hline 3. & $\delta$-3-Carene & 10.271 & 919 & $0.25 \pm 0.01$ \\
\hline 4. & $\alpha$-Pinene & 10.436 & 891 & $0.72 \pm 0.013$ \\
\hline 5. & Benzylin & 11.126 & 909 & $5.29 \pm 0.31$ \\
\hline 6. & Santolina triene & 11.361 & 837 & $0.4 \pm 0.001$ \\
\hline 7. & 4-Carene & 12.111 & 893 & $0.69 \pm 0.023$ \\
\hline 8. & Eucalyptol & 12.827 & 841 & $21.26 \pm 1.97$ \\
\hline 9. & $\gamma$-Terpinene & 13.837 & 928 & $1.52 \pm 0.014$ \\
\hline 10. & 1,5-Dimethyl-1,5-cyclooctadiene & 14.227 & 883 & $0.18 \pm 0.001$ \\
\hline 11. & 5,5-Dimethyl-2-ethyl-1,3-cyclopentadiene & 14.352 & 881 & $0.18 \pm 0.001$ \\
\hline 12. & Ocimene & 14.778 & 817 & $0.07 \pm 0.004$ \\
\hline 13. & $\alpha$-Terpinolene & 14.923 & 917 & $0.29 \pm 0.001$ \\
\hline 14. & Linalool oxide & 15.018 & 803 & $0.04 \pm 0.001$ \\
\hline 15. & Arachidonic acid methyl ester & 15.683 & 840 & $0.17 \pm 0.02$ \\
\hline 16. & Cosmene & 15.99 & 803 & $0.01 \pm 0.001$ \\
\hline 17. & Norbornane & 16.11 & 847 & $0.02 \pm 0.001$ \\
\hline 18. & 4,7-Dimethyl-4,4a,5,6-tetrahydrocyclopenta[c]pyran-1,3-dione & 16.508 & 910 & $0.21 \pm 0.01$ \\
\hline 19. & cis-Carveol & 16.843 & 829 & $0.01 \pm 0.001$ \\
\hline 20. & Endo-Borneol & 18.584 & 909 & $29.06 \pm 1.24$ \\
\hline 21. & Bornyl chloride & 18.769 & 829 & $5.79 \pm 0.09$ \\
\hline 22. & $\alpha$-Terpineol & 19.324 & 907 & $4.48 \pm 0.07$ \\
\hline 23. & Menthen-9-ol & 22.41 & 808 & $4.2 \pm 0.023$ \\
\hline 24. & Geranyl Phenylacetate & 24.966 & 803 & $0.48 \pm 0.001$ \\
\hline 25. & Copaene & 25.547 & 900 & $0.93 \pm 0.015$ \\
\hline 26. & $\beta$-Bourbonene & 25.807 & 921 & $0.78 \pm 0.011$ \\
\hline 27. & Jasmone & 26.137 & 899 & $0.07 \pm 0.001$ \\
\hline 28. & Caryophyllene & 26.967 & 924 & $0.95 \pm 0.009$ \\
\hline 29. & $\beta$-Cubebene & 27.302 & 902 & $0.11 \pm 0.004$ \\
\hline 30. & D-Germacrene & 27.753 & 871 & $0.05 \pm 0.001$ \\
\hline 31. & 1,1,4,8-Tetramethyl-4,7,10-cycloundecatriene & 28.113 & 889 & $0.24 \pm 0.006$ \\
\hline 32. & epi-Bicyclosesquiphellandrene & 29.288 & 896 & $0.78 \pm 0.008$ \\
\hline 33. & 5,7-Diethyl-5,6-decadien-3-yne & 29.618 & 929 & $0.06 \pm 0.002$ \\
\hline 34. & $\gamma$-Cadinene & 29.923 & 919 & $0.23 \pm 0.008$ \\
\hline 35. & $\alpha$-Cadinene & 30.148 & 916 & $6.09 \pm 0.1$ \\
\hline 36. & $\alpha$-Ferulene & 30.644 & 800 & $0.02 \pm 0.001$ \\
\hline 37. & 3-Ethyl-3-hydroxyandrostan-17-one & 30.644 & 824 & $0.02 \pm 0.002$ \\
\hline 38. & Cadala-1(10),3,8-Triene & 30.779 & 830 & $0.02 \pm 0.001$ \\
\hline 39. & cis- $\alpha$-Copaene- 8 -ol & 31.029 & 741 & $0.05 \pm 0.001$ \\
\hline 40. & Bicyclo[5.2.0]nonane & 31.319 & 818 & $0.03 \pm 0.001$ \\
\hline 41. & Acetic Acid,4a-Methyl-2,3,4,4a,5,6,7,8 Octahydronaphthalen-2-yl & 31.489 & 732 & $0.05 \pm 0.001$ \\
\hline 42. & Benzoic acid, 3-hexenyl ester & 31.649 & 843 & $0.07 \pm 0.001$ \\
\hline 43. & Retinal & 31.729 & 829 & $0.07 \pm 0.001$ \\
\hline 44. & $p$-Menthane & 31.864 & 784 & $0.07 \pm 0.001$ \\
\hline 45. & Aromadendrane & 32.649 & 839 & $0.06 \pm 0.001$ \\
\hline 46. & [2,2-dimethyl-4-(3-methylbut-2-enyl)-6-methylidenecyclohexyl] methanol & 32.829 & 875 & $0.02 \pm 0.001$ \\
\hline 47. & $\alpha$-Cubebene & 33.38 & 844 & $1.48 \pm 0.031$ \\
\hline 48. & Valencene & 33.515 & 827 & $0.31 \pm 0.002$ \\
\hline 49. & Epizonarene & 33.845 & 855 & $7.89 \pm 0.91$ \\
\hline 50. & $\gamma$-Gurjunene & 34.45 & 864 & $2.17 \pm 0.09$ \\
\hline 51. & Isophorone & 34.78 & 880 & $0.53 \pm 0.003$ \\
\hline 52. & Timnodonic acid & 41.238 & 738 & $0.37 \pm 0.001$ \\
\hline \multicolumn{4}{|c|}{ Total } & 100 \\
\hline
\end{tabular}


Table 2. The metabolic enzymes inhibitory and the antioxidant activities $\mathrm{IC}_{50}$ values of $S$. viticina essential oil compared with the required positive controls.

\begin{tabular}{|c|c|c|c|c|c|c|c|}
\hline \multicolumn{2}{|c|}{$\begin{array}{c}\alpha \text {-Amylase Inhibitory Activity } \\
\mathrm{IC}_{50}(\mu \mathrm{g} / \mathrm{mL}), \pm \mathrm{SD}\end{array}$} & \multicolumn{2}{|c|}{$\begin{array}{c}\alpha \text {-Glucosidase Inhibitory } \\
\text { Activity IC } \mathrm{IC}_{50}(\mu \mathrm{g} / \mathrm{mL}), \pm \mathrm{SD}\end{array}$} & \multicolumn{2}{|c|}{$\begin{array}{l}\text { Antioxidant Activity } \\
\mathrm{IC}_{50}(\mu \mathrm{g} / \mathrm{mL}), \pm \mathrm{SD}\end{array}$} & \multicolumn{2}{|c|}{$\begin{array}{l}\text { Antilipase Activity IC } \\
(\mu \mathrm{g} / \mathrm{mL}), \pm \mathrm{SD}\end{array}$} \\
\hline $\mathrm{EO}$ & $\begin{array}{l}\text { Acarbose } \\
\text { (Positive } \\
\text { control) }\end{array}$ & $\mathrm{EO}$ & $\begin{array}{l}\text { Acarbose } \\
\text { (Positive } \\
\text { control) }\end{array}$ & $\mathrm{EO}$ & $\begin{array}{l}\text { Trolox } \\
\text { (Positive } \\
\text { control) }\end{array}$ & $\mathrm{EO}$ & $\begin{array}{l}\text { Orlistat } \\
\text { (Positive } \\
\text { control) }\end{array}$ \\
\hline $45.22 \pm 1.1$ & $28.89 \pm 1.22$ & $63.09 \pm 0.26$ & $37.15 \pm 0.33$ & $\begin{array}{l}19.95 \pm \\
2.08\end{array}$ & $2.23 \pm 1.57$ & $\begin{array}{c}501.18 \pm \\
0.38\end{array}$ & $12.3 \pm 0.33$ \\
\hline
\end{tabular}

\subsection{Antimicrobial Capacity}

The microdilution assay was used to determine the antimicrobial potential of $S$. viticina essential oil against Methicillin-resistant Staphylococcus aureus (MRSA), S. aureus, E. faecium, S. sonnie, P. aeruginosa, E. coli, E. floccosum, and C. albicans. The EO inhibited the growth of all of the studied bacterial and fungal strains to different degrees. The highest antibacterial activity was recorded against MRSA, followed by E. coli with MIC values of 0.039 and $0.078 \mathrm{mg} / \mathrm{mL}$, respectively, while the highest antifungal activity observed was against $E$. floccosum with MIC value of $0.78 \mathrm{mg} / \mathrm{mL}$ as presented in Table 3 .

Table 3. Antimicrobial MIC values of S. viticina EO.

\begin{tabular}{ccc}
\hline Microorganisms & Sources & MIC, $(\mathbf{m g} / \mathbf{m L})$ \\
\hline Staphylococcus aureus & ATCC 25923 & 1.5625 \\
Escherichia coli & ATCC 25922 & 0.078 \\
Pseudomonas aeruginosa & ATCC 27853 & 3.125 \\
Shigella sonnie & ATCC 25931 & 3.125 \\
Methicillin-Resistant Staphylococcus aureus (MRSA) & Clinical isolate & 0.039 \\
Enterococcus faecium & ATCC 10231 & 1.5625 \\
Candida albicans & ATCC 90028 & 3.125 \\
Epidermophyton floccosum & ATCC 700221 & 0.78 \\
\hline
\end{tabular}

\subsection{Cyclooxygenase Inhibitory Effect}

The cyclooxygenase enzymatic inhibitory activity assay of S. viticina EO was conducted utilizing Cayman Chemical ELISA kit No. 560131. The calculated percentage inhibitions of COX-2 as well as for COX-1 were $98 \%$ and $99 \%$ at EO concentrations of 0.25 and $0.5 \mu \mathrm{g} / \mathrm{mL}$, respectively. The results showed that the $S$. viticina EO displayed a strong, but not selective inhibition activity towards both COX-2 and COX-1 enzymes.

\subsection{Cytotoxic Effect}

As shown in Figure 1, treatment of Colo-205 cells with 1, 0.5 and $0.25 \mathrm{mg} / \mathrm{mL}$ of EO induced cytotoxicity significantly $(p \leq 0.0001)$ by approximately $90 \%, 90 \%$, and $55 \%$, respectively. Treatment of HeLa cells with $2.5,1.25$ and $0.625 \mathrm{mg} / \mathrm{mL}$ of EO induced cytotoxicity significantly ( $p \leq 0.0001$ ) by approximately $95 \%, 95 \%$, and $80 \%$, respectively, while at a concentration of $0.1875 \mathrm{mg} / \mathrm{mL}$ did not exhibit a significant effect as presented in Figure 2. 


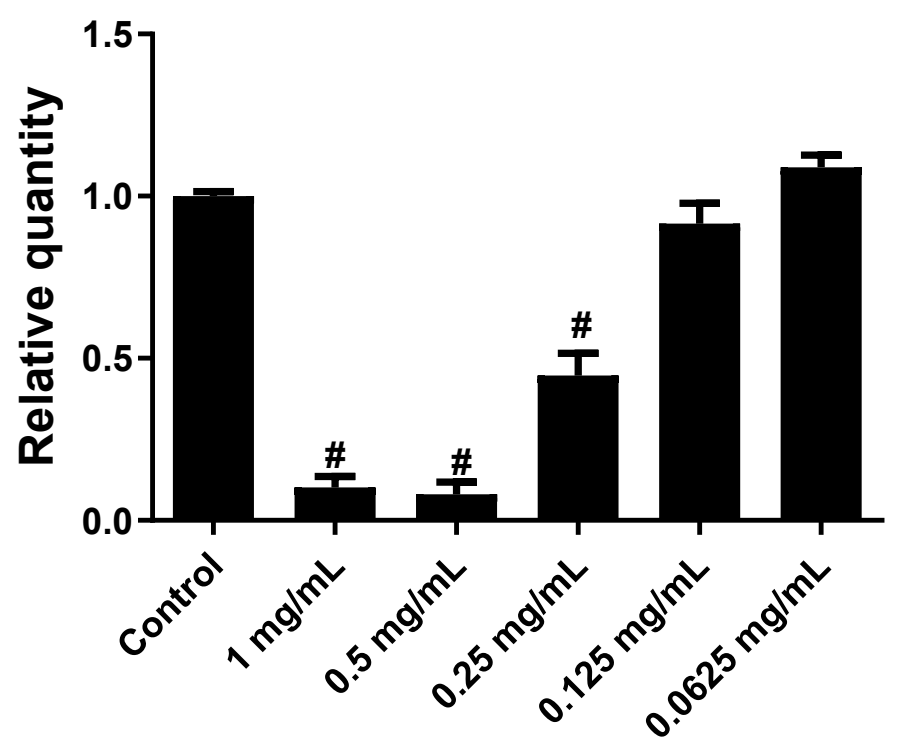

Concentration

Figure 1. The effect of $S$. viticina EO on the cytotoxicity of Colo-205 cells. Results were depicted as relative quantities (RQs) compared to the control (only media). \# where $P<0.0001$. Error bars represent SD.

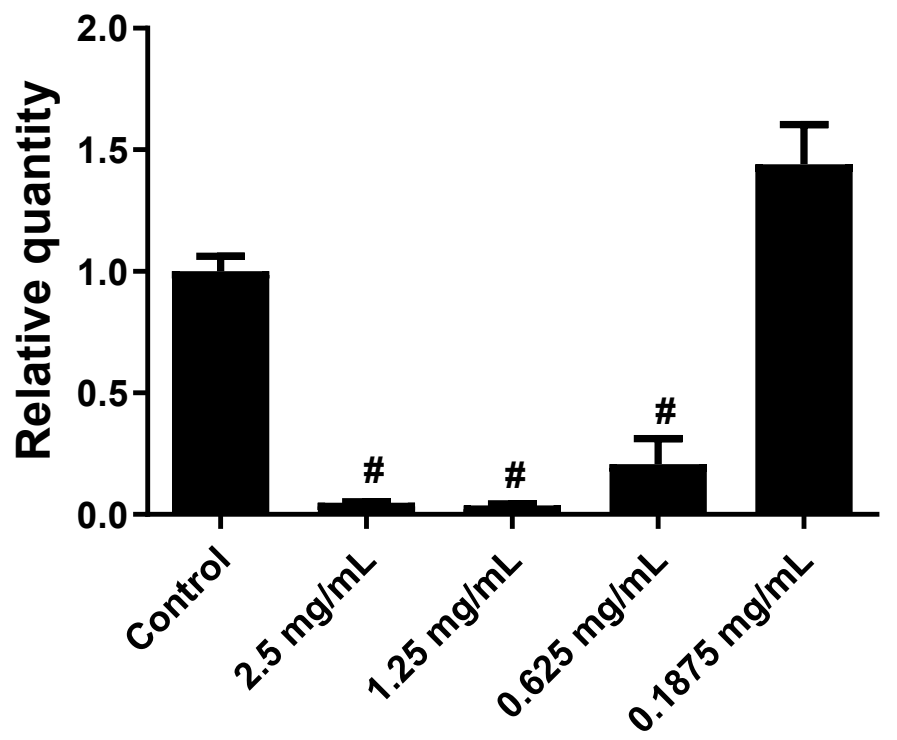

\section{Concentration}

Figure 2. The effect of S. viticina EO on the cytotoxicity of HeLa cells. Results were depicted as relative quantities (RQs) compared to the control (only media). \# Where $P<0.0001$. Error bars represent SD.

\section{Discussion}

The study of plants secondary metabolites represents a worldwide strategy for the search of new therapeutic agents since plants contain a wide range of biologically active compounds. Medicinal plants are extensively used in traditional medicine due to their healing properties. In order to set up an inventory of their biological activities, it is important to link scientific studies with clinical observations and traditional knowledge. This investigation is part of this scenario and was aimed to screen the biological activity of Stachys viticina essential oil. To the best of the authors' knowledge, the 
full chemical constituents, as well as the antimicrobial, anticancer, antioxidant, metabolic enzymes and cyclooxygenase inhibitory properties of S. viticina $\mathrm{EO}$ have not been reported to date.

\subsection{Phytochemical Components of S. viticina Essential Oil}

The S. viticina EO was isolated using an eco-friendly microwave-ultrasonic technique and the components of the EO were identified using GC-MS technology. The primary components were determined to be endo-borneol, eucalyptol, epizonarene, $\alpha$-cadinene, bornyl chloride, and benzylin with percentage areas of $29.06 \pm 1.24,21.26 \pm 1.97,7.89 \pm 0.91,6.09 \pm 0.1,5.79 \pm 0.09$, and $5.29 \pm 0.31$, respectively. The chromatogram of S. viticina EO is shown in Figure S1. The retention times and mass fragmentation data of the 52 compounds identified are listed in Table 1.

Recently, Gören et al. reported the identification of only 20 compounds from EO chemical composition of S. viticina aerial parts (flowering tops, stems, and leaves) growing in Turkey, of which $\beta$-caryophyllene (62.3\%), farnesyl acetate (8.9\%) and $\alpha$-bisabolol (4.4\%) were the major components [12]. The difference in the results could be attributed to the difference in the area of plant growth, extraction conditions and/or to the fact that only the leaves were used in this investigation, while in Goren et al. study the aerial parts (flowers, leaves and stems) were used.

\subsection{Metabolic Enzymes Inhibitory Activity}

The metabolic pancreatic $\alpha$-amylase and the intestinal $\alpha$-glucosidase enzymes play a vital role in the digestion of carbohydrates such as starch, dextrin, maltotriose, maltose, glucose and table sugar. In fact, diabetes, overweight and obesity can be controlled by the inhibition of these enzymes due to their ability to retard the carbohydrate's digestion process and to improve glucose tolerance in patients suffering from type II of diabetes [13].

As shown in Figures S3 and S4, S. viticina EO displayed $\alpha$-amylase pancreatic enzyme and $\alpha$-glucosidase inhibitory activity in vitro, with $\mathrm{IC}_{50}$ values of $45.22 \pm 1.1 \mu \mathrm{g} / \mathrm{mL}$ and $63.09 \pm 0.26 \mu \mathrm{g} / \mathrm{mL}$, respectively, compared to that of the antidiabetic drug acarbose which has $\alpha$-amylase and $\alpha$-glucosidase inhibitory effects with IC 50 values of $28.89 \pm 1.22 \mu \mathrm{g} / \mathrm{mL}$ and $37.15 \pm 0.33 \mu \mathrm{g} / \mathrm{mL}$, respectively. This means that S. viticina EO inhibited $56.52 \%$ and $69.82 \%$ of $\alpha$-amylase and $\alpha$-glucosidase activity, respectively.

There are many reports on the inhibitory effect of EO extracted from different plant species on the $\alpha$-amylase and $\alpha$-glycosidase. Loizzo et al. reported that the Cedrus libani wood EO exhibited an $\alpha$-amylase inhibitory effect with $\mathrm{IC}_{50}$ of $140 \mu \mathrm{g} / \mathrm{mL}$ [14]. Ma et al. found that the EOs extracted from Pyrola calliantha entire plant, Senecio scandens flowers and of Schisandra chinensis roots have $\alpha$-glycosidase inhibitory activity with $\mathrm{IC}_{50}$ values of $22.11,130.4$ and $19.25 \mu \mathrm{g} / \mathrm{mL}$, respectively [15]. Another study conducted by Dang et al. revealed that the Citrus medica var. sarcodactylis (Buddha's hand) fruits EO inhibited an $\alpha$-glucosidase enzyme with an $\mathrm{IC}_{50}$ value of $412.2 \mu \mathrm{g} / \mathrm{mL}$ [16].

However, the $\mathrm{IC}_{50}$ values showed that $S$. viticina $\mathrm{EO}$ displayed a stronger inhibitory activity on $\alpha$-amylase than on $\alpha$-glucosidase activity, and therefore this finding is therapeutically important especially in preventing some of the side effects associated with the use of chemical $\alpha$-glucosidase and $\alpha$-amylase inhibitory agents [17]. The observed $\alpha$-amylase and $\alpha$-glucosidase inhibitory activity of the S. viticina $\mathrm{EO}$ gives credence to the fact that $S$. viticina $\mathrm{EO}$ could be promising antidiabetic medicine after in vivo and clinical trials.

Therapeutic agents that can inhibit the pancreatic lipase enzyme have gained much importance in recent years. Obviously, the inhibition of pancreatic lipase enzyme retards the lipids digestion and consequently lower the rate of fats absorption and decrease the levels of triglyceride in blood serum which may also cause a reduction of body weight. The $\mathrm{EO}$ of $S$. viticina revealed weak porcine pancreatic lipase inhibitory activity with an $\mathrm{IC}_{50}$ value of $501.18 \pm 0.38 \mu \mathrm{g} / \mathrm{mL}$ compared to that of antiobesity available drug Orlistat $\left(\mathrm{IC}_{50}=12.3 \pm 0.33 \mu \mathrm{g} / \mathrm{mL}\right)$. Salameh et al. reported that $\mathrm{EO}$ of Micromeria fruticosa serpyllifolia leaves (Lamiaceae) exhibited potent antilipase activity with an $\mathrm{IC}_{50}$ value of $39.81 \mu \mathrm{g} / \mathrm{mL}$, which is better than that of $S$. viticina $\mathrm{EO}\left(\mathrm{IC}_{50}=501.18 \pm 0.38 \mu \mathrm{g} / \mathrm{mL}\right)$ [18]. 


\subsection{Antioxidant Activity}

Due to its simplicity and high sensitivity, the widely used DPPH assay for radical scavenging was employed to assess the antioxidant activity of S. viticina EO [19]. The results of the present work showed that the EO exhibited antioxidant activity with an $\mathrm{IC}_{50}$ value of $19.95 \pm 2.08 \mu \mathrm{g} / \mathrm{mL}$, less than that of the positive control (Trolox) which has an $\mathrm{IC}_{50}$ value of $2.23 \pm 1.57 \mu \mathrm{g} / \mathrm{mL}$. Previous studies demonstrated that various Stachys species exhibited good antioxidant activity. A study conducted by Kukić et al. revealed that $S$. anisochila, S. beckeana, S. plumose, and S. alpina ssp. dinarica have antioxidant potential with $\mathrm{IC}_{50}$ values of $17.9,20.9,101.61$, and $26.14 \mu \mathrm{g} / \mathrm{mL}$, respectively [20]. The EO of $S$. inflate, growing Iran, exhibited antioxidant activity with an $\mathrm{IC}_{50}$ value of $89.50 \pm 0.65 \mu \mathrm{g} / \mathrm{mL}$ [21]. Furthermore, A study performed by Conforti et al. on the antioxidant activity of the EOs extracted from various Stachys species from different regions of the Mediterranean area revealed that S. palustris, S. cretica, and S. hydrophila displayed the highest antiradical effect, with $\mathrm{IC}_{50}$ values of $48.2,65.2$ and $66.4 \mu \mathrm{g} / \mathrm{mL}$, respectively [22].

\subsection{Cyclooxygenase Inhibitory Assay}

Non-steroidal anti-inflammatory molecules have the potentials to reduce inflammation and relieve pains in the human body which is associated with the increase of prostaglandin levels. However, several traditional herbal products have been used to reduce pain sensation, inflammations and fever [23]. The current cyclooxygenase inhibitory assay revealed that S. viticina EO caused a $98 \%$ and $99 \%$ inhibition of COX-1 and COX-2 enzymes activity at concentrations of 0.25 and $0.5 \mu \mathrm{g} / \mathrm{mL}$, respectively. S. viticina EO exhibited cyclooxygenase inhibitory activity against COX-1 and Cox-2 with $\mathrm{IC}_{50}$ values of 0.25 and $0.5 \mu \mathrm{g} / \mathrm{mL}$, respectively, similar to those $\mathrm{IC}_{50}$ values of the positive control (the NSAID etodolac).

\subsection{Cytotoxic Activity}

Cytotoxicity assays have gained increasing interest over recent years due to their great value in the biological screening of insecticide, herbicides and anticancer agents [24]. These assays are proved to be reliable, quick, cheap and reproducible. Various types of cytotoxic tests, such as luminometric, fluorometric, dye exclusion and colorimetric assays, are used in the fields of pharmacology and toxicology [25]. The significant antimicrobial activity of S. viticina EO encouraged us to evaluate its cytotoxicity. The potential cytotoxicity of the S. viticina EO towards HeLa (cervical adenocarcinoma) and Colo-205 (colon) cancer cells was evaluated using the MTS assay. As shown in Figure 1; Figure 2, treatment of Colo-205 cells with $0.5 \mathrm{mg} / \mathrm{mL}$ of S. viticina EO induced the best cytotoxic effect $(90 \%)$, while treatment of HeLa cells with $2.5 \mathrm{mg} / \mathrm{mL}$ of EO induced the highest cytotoxicity (95\%). The $S$. viticina EO displayed very strong cytotoxicity against HeLa and Colo-205 cancer cells.

In a previous study conducted in our laboratory, Jaradat et al. reported that Teucrium pruinosum EO at a dose of $7.67 \mathrm{mg} / \mathrm{mL}$ induced cytotoxic activity on HeLa cancer cells by $90-95 \%$. The cytotoxicity of $S$. viticina $\mathrm{EO}$ against HeLa cancer cells is triple that induced by Teucrium pruinosum $\mathrm{EO}$ (Lamiaceae) [26].

\subsection{Antimicrobial Capacity}

The microdilution assay was used to assess the antimicrobial activity of $S$. viticina $\mathrm{EO}$ against MRSA, S. aureus, E. faecium, S. sonnie, P. aeruginosa, E. coli, E. floccosum, and C. albicans. The S. viticina EO inhibited the growth of all the screened pathogens. In particular, the S. viticina EO exhibited potent antibacterial activity against MRSA with MIC value of $0.039 \mathrm{mg} / \mathrm{mL}$, which is two folds more potential than the inhibition activity against $E$. coli $(\mathrm{MIC}=0.078 \mathrm{mg} / \mathrm{mL}$ ). Moreover, the $\mathrm{EO}$ of $S$. viticina plant inhibited the growth of all the studied fungal strains, especially inhibited potentially the growth of $E$. floccosum with MIC value of $0.78 \mathrm{mg} / \mathrm{mL}$. 


\section{Materials and Methods}

\subsection{Chemical Reagents}

All the experiments in the current study were carried out utilizing commercially available chemicals and reagents unless otherwise stated.

\subsection{Equipment}

A gas chromatograph (Clarus 500-Perkin Elmer, Singapore), Mass Spectrometer (Clarus 560D-Perkin Elmer), microscope (IX-73-inverted, Olympus (China) CO.,LTD, Beijing, China), UV-Visible Spectrophotometer (Jenway-7315, Staffordshire, UK), microwaves-ultrasonic reactor-extractor (CW-2000, Gloria Wang Zhejiang Nade Scientific Instrument Co., Ltd., Zhejiang, China), Balance (Rad-weight, International Weighing Review, Toruńska, Poland), sonicator (MRC, 2014-207, MRC Lab., Haifa, Israel), water bath (LabTech, 2011051806, Thermo Fisher Scientific, Seoul, South Korea), incubator (Nüve, 06-3376, Ankara, Turkey), vortexer (090626691, Heidolph Company, Schwabach, Germany), autoclave (MRC, A13182, Mrc lab., Haifa, Israel), grinder (Molineux I, Jiangmen, China) and microplate reader (6000, Unilab, Fort Lauderdale, FL USA) were utilized in the current investigation.

\subsection{Herbal Material}

Stachys viticina leaves were collected in March 2018 from the Nablus area, Palestine. The taxonomical characterization of the plant was established at the Pharmacy Department at An-Najah National University and deposited under the voucher specimen number (Pharm-PCT-2341). Later on, $S$. viticina leaves were cleaned, rinsed at least three times with distilled water and then dried in the shade at $25 \pm 2{ }^{\circ} \mathrm{C}$ and $55 \pm 5 \mathrm{RH}$ of humidity for three weeks. The dried leaves were cut into small pieces which were kept in special paper bags for farther experimental work [27].

\subsection{Isolation of S. viticina Essential Oil}

The EO of S. viticina plant was extracted using the microwave and ultrasonic apparatus as reported by Jaradat et al. [28]. Dried S. viticina powder (100 g) and distilled water $(0.5 \mathrm{~L})$ were placed in a round bottomed flask and exposed to micro- and ultrasonic- waves at a fixed power of $1000 \mathrm{~W}$ at $100{ }^{\circ} \mathrm{C}$ for $10 \mathrm{~min}$. The extracted EO was collected into an amber glass bottle and kept in the refrigerator at $2-8{ }^{\circ} \mathrm{C}$ for further experiments.

\subsection{GC-MS Characterization of S. viticina Essential Oil}

The separation was achieved on a Perkin Elmer Elite-5-MS fused-silica capillary column (30 $\mathrm{m} \times$ $0.25 \mathrm{~mm}$, film thickness $0.25 \mu \mathrm{m}$ ), using helium as carrier gas at a standard flow rate of $1.1 \mathrm{~mL} / \mathrm{min}$. The temperature of the injector was adjusted at $250{ }^{\circ} \mathrm{C}$ with an initial temperature of $50{ }^{\circ} \mathrm{C}$, initial hold $5 \mathrm{~min}$, and ramp $4.0^{\circ} \mathrm{C} / \mathrm{min}$ to $280^{\circ} \mathrm{C}$. The total running time was $62.50 \mathrm{~min}$ and the solvent delay was from 0 to $4.0 \mathrm{~min}$. MS scan time was from 4 to $62.5 \mathrm{~min}$, covering mass range 50.00 to 300.00 $\mathrm{m} / \mathrm{z}$. The chemical ingredients of the EO were characterized by comparing their mass spectra with the reference spectra in the MS Data Centre of the National Institute of Standards and Technology, and by matching their Kovats and retention indices with values reported in the literature [29,30]. In addition, the EOs Kovats and retention indices with values were compared with $20 \%$ of HPLC grade of reference EOs including $\alpha$-pinene, eucalyptol, caryophyllene, $\gamma$-terpinene, ocimene, endo-borneol, $\alpha$-terpineol, jasmone, $\alpha$-cadinene, $p$-menthane that were purchased from Sigma-Aldrich, Hamburg, Germany) [31].

\subsection{Porcine Pancreatic Lipase Inhibitory Assay}

A porcine pancreatic lipase inhibition assay was conducted in order to assess the anti-obesity activity of S. viticina EO. The drug Orlistat, an anti-obesity, and anti-lipase agent, was used as a positive control. The porcine pancreatic lipase inhibitory method was performed according to the protocol 
described by Zheng et al. with slight modifications [32]. A $500 \mu \mathrm{g} / \mathrm{mL}$ stock solution from the EO was dissolved in dimethyl sulfoxide (DMSO): methanol (1:9), and five different dilutions (50, 100, 200, 300 and $400 \mu \mathrm{g} / \mathrm{mL}$ ) were prepared. Then, a $1 \mathrm{mg} / \mathrm{mL}$ stock solution of porcine pancreatic lipase was freshly prepared before use and was dispersed in Tris- $\mathrm{HCl}$ buffer. The substrate used was $p$-nitrophenyl butyrate (PNPB) (Sigma-Aldrich, Hamburg, Germany), prepared by dissolving $20.9 \mathrm{mg}$ of it in $2 \mathrm{~mL}$ of acetonitrile. $0.1 \mathrm{~mL}$ of porcine pancreatic lipase $(1 \mathrm{mg} / \mathrm{mL})$ and $0.2 \mathrm{~mL}$ of the EO from each of the concentration series were placed in 5 different working test tubes and mixed. The resulting mixture was adjusted to $1 \mathrm{~mL}$ by adding Tri- $\mathrm{HCl}$ solution and incubated at $37^{\circ} \mathrm{C}$ for $15 \mathrm{~min}$. thereafter, 0.1 $\mathrm{mL}$ of $p$-nitrophenyl butyrate solution was added to each test tube and the mixture was incubated for $30 \mathrm{~min}$. at $37^{\circ} \mathrm{C}$. The pancreatic lipase activity was determined by measuring the hydrolysis of PNPB into $p$-nitrophenolate ions at $410 \mathrm{~nm}$ using a UV-Vis spectrophotometer. The same procedure was repeated for the positive control sample (Orlistat, Sigma-Aldrich). The inhibitory percentage of the anti-lipase activity was calculated using the following equation:

$$
\text { Lipase inhibition } \%=(\mathrm{AB}-\mathrm{Ats}) / \mathrm{AB} \times 100 \%
$$

where AB is the recorded absorbance of the blank solution and Ats is the recorded absorbance of the tested sample solution.

\section{7. $\alpha$-Amylase Inhibition Assay}

The $\alpha$-amylase inhibitory activity of $S$. viticina EO was assessed according to the standard method reported by Nyambe-Silavwe et al. with minor modifications [33]. The EO was dissolved in DMSO (Riedel-de-Haen, Hamburg, Germany) and then diluted with a buffer $\left(\left(\mathrm{Na}_{2} \mathrm{HPO}_{4} / \mathrm{NaH}_{2} \mathrm{PO}_{4}(0.02 \mathrm{M})\right.\right.$, $\mathrm{NaCl}(0.006 \mathrm{M})$ at $\mathrm{pH}$ 6.9) to a concentration of $1000 \mu \mathrm{g} / \mathrm{mL}$. A concentration series of 10, 50, 70, 100 and $500 \mu \mathrm{g} / \mathrm{mL}$ were prepared. $0.2 \mathrm{~mL}$ of porcine pancreatic $\alpha$-amylase enzyme solution (Sigma-Aldrich, St. Louis, MO, USA) with a concentration of 2 units $/ \mathrm{mL}$ was mixed with $0.2 \mathrm{~mL}$ of the EO and incubated at $30{ }^{\circ} \mathrm{C}$ for $10 \mathrm{~min}$. Thereafter, $0.2 \mathrm{~mL}$ of freshly prepared starch solution $(1 \%)$ was added and the mixture was incubated for at least $3 \mathrm{~min}$. The reaction was stopped by addition of $0.2 \mathrm{~mL}$ dinitrosalicylic acid (DNSA) (Alf_aAesar, Lancashire, UK), then the mixture was diluted with $5 \mathrm{~mL}$ of distilled water and heated in a water bath at $90^{\circ} \mathrm{C}$ for $10 \mathrm{~min}$. The mixture was left to cool down to room temperature and the absorbance was measured at $540 \mathrm{~nm}$. A blank was prepared following the same procedure by replacing the $S$. viticina $\mathrm{EO}$ with $0.2 \mathrm{~mL}$ of the buffer.

Acarbose (Sigma-Aldrich, USA) was used as a positive control and prepared to adopt the same procedure described above. The $\alpha$-amylase inhibitory activity was calculated using the following equation:

$$
\% \text { of } \alpha \text {-amylase inhibition }=\left(\mathrm{A}_{\mathrm{b}}-\mathrm{A}_{\mathrm{S}}\right) / \mathrm{A}_{\mathrm{b}} 100 \%
$$

where $A_{b}$ is the absorbance of the blank and $A_{S}$ is the absorbance of the tested sample or control.

\section{8. $\alpha$-Glucosidase Inhibitory Activity Assay}

The $\alpha$-glucosidase inhibitory activity of $S$. viticina EO was performed according to the standard protocol with a slight modification [34]. A mixture of $50 \mu \mathrm{L}$ of phosphate buffer $(100 \mathrm{mM}, \mathrm{pH} 6.8), 10$ $\mu \mathrm{L} \alpha$-glucosidase $(1 \mathrm{U} / \mathrm{mL}$ ) (Sigma-Aldrich, USA) and $20 \mu \mathrm{L}$ of varying concentrations of $S$. viticina EO $(100,200,300,400$ and $500 \mu \mathrm{g} / \mathrm{mL})$ were placed in 5 different test tubes. After $15 \mathrm{~min}$. incubation at 37 ${ }^{\circ} \mathrm{C}, 20 \mu \mathrm{L}$ of pre-incubated $5 \mathrm{mM}$ PNPG (Sigma-Aldrich, USA) was added as the substrate to each test tube and the reaction mixtures were incubated at $37^{\circ} \mathrm{C}$ for additional $20 \mathrm{~min}$. The reaction was terminated by adding $50 \mu \mathrm{L}$ of aqueous $\mathrm{Na}_{2} \mathrm{CO}_{3}(0.1 \mathrm{M})$. The absorbance of the released $p$-nitrophenol was measured by a UV/Vis spectrophotometer at $405 \mathrm{~nm}$. Acarbose at similar concentrations as the plant EO was used as the positive control. The inhibition percentage was calculated using the following equation:

$$
\% \text { of } \alpha \text {-amylase inhibition }=\left(\mathrm{A}_{\mathrm{b}}-\mathrm{A}_{\mathrm{S}}\right) / \mathrm{A}_{\mathrm{b}} 100 \%
$$


where $A_{b}$ is the absorbance of the blank and $A_{S}$ is the absorbance of the tested sample or control [35].

\subsection{Antioxidant Assay}

For estimation of $S$. viticina EO antioxidant potential, a solution of EO $(1 \mathrm{mg} / \mathrm{mL})$ in methanol was serially diluted with methanol to obtain concentration of $1,2,3,5,7,10,20,30,40,50,80$ and $100 \mu \mathrm{g} / \mathrm{mL}$. Then, DPPH (2,2-diphenyl-1-picrylhydrazyl) reagent (Sigma, New York, NY, USA) was dissolved in $0.002 \% w / v$ methanol and mixed with the previously prepared working concentrations in a 1:1 ratio. The same procedures were repeated for Trolox (Sigma-Aldrich, Darmstadt, Denmark) which was used as a positive control. All of the solutions were kept in a dark chamber for $30 \mathrm{~min}$ at ordinary temperature.

Then, their absorbance values were measured at a wavelength of $517 \mathrm{~nm}$ utilizing a UV-Visible spectrophotometer. The DPPH inhibition potential by S. viticina EO and Trolox were determined employing the following equation:

$$
\text { DPPH inhibition }(\%)=\left(\mathrm{abs}_{\text {blank }}-\mathrm{abs}_{\text {sample }}\right) / \mathrm{abs}_{\text {blank }} 100 \%
$$

where $a b s_{\text {blank }}$ is the blank absorbance and abs sample is the absorbance of the samples. The antioxidant half-maximal inhibitory concentration $\left(\mathrm{IC}_{50}\right)$ of S. viticina $\mathrm{EO}$ and Trolox were assessed using BioDataFit-E1051 program [36].

\subsection{Antimicrobial Activities of S. viticina Essential Oil}

The fungal and bacterial isolates used in this study were from the American Type Culture Collection (ATCC, Manassas, VA, USA) and from selected MRSA species (), that were obtained from the Palestinian area at clinical settings and exhibited multi-antibiotic resistance. The screened microorganisms included three Gram-positive bacteria (MRSA, Enterococcus faecium (ATCC 700221) and S. aureus (ATCC 25923)), three of Gram-negative bacteria (Shigella sonnie (ATCC 25931), Pseudomonas aeruginosa (ATCC 27853) and Escherichia coli (ATCC 25922) and two fungal strains (Epidermophyton floccosum (ATCC 10231) and Candida albicans (ATCC 90028)).

The microdilution assay was utilized to assess the antimicrobial activity of S. viticina EO against bacterial and yeast strains. A total of $8.8 \mathrm{~g}$ of Mueller-Hinton broth were dissolved in $400 \mathrm{~mL}$ of distilled water under heat and boiled for $1 \mathrm{~min}$. The obtained solution was autoclaved and kept at $4{ }^{\circ} \mathrm{C}$ until use. $100 \mu \mathrm{L}$ from the broth was placed in each well of the microdilution tray. Then, $100 \mu \mathrm{L}$ of the EO was added to the first well and the mixture was shacked. Thereafter, serial dilutions up to well \#11 were performed. Well \#12 did not contain any EO and was considered as a positive control for microbial growth. A fresh bacterial colony was picked from an overnight agar culture and was prepared to match the turbidity of the $0.5 \mathrm{McF}$ arland standards to provide a bacterial suspension of $1.5 \times 10^{8} \mathrm{CFU}$ (colony forming unit)/mL. The suspension was diluted with broth by a ratio of $1: 3$ to a final concentration of $5 \times 10^{7} \mathrm{CFU}$. Then, $1 \mu \mathrm{L}$ of the bacterial suspension was added to each well except well \#11, which was a negative control for microbial growth. Finally, the plate was incubated at $35^{\circ} \mathrm{C}$ for $18 \mathrm{~h}$.

The microdilution method for the yeast $C$. albicans was performed as described above, except that after matching the yeast suspension with the McFarland standard, it was diluted with $\mathrm{NaCl}$ by a ratio of 1:50, followed by 1:20, and $100 \mu \mathrm{L}$ was placed in the wells. The plate was incubated for $48 \mathrm{~h}$ instead of $18 \mathrm{~h}$.

To investigate anti-Epidermatophyton floccosum mold activity of the $S$. viticina $\mathrm{EO}$, an agar dilution method was performed. Sabouraud dextrose agar (SDA) was prepared, of which $1 \mathrm{~mL}$ was placed in each tube and kept in a $40{ }^{\circ} \mathrm{C}$ water bath. $1 \mathrm{~mL}$ of the EO was mixed with $1 \mathrm{~mL}$ of SDA in the first tube and serial dilutions were performed in six tubes, except tube \#6, which did not contain any plant material and considered as a positive control for microbial growth. 
After the SDA was solidified, the spores of the mold culture were dissolved using distilled water containing $0.05 \%$ Tween 80 and scratched from the plate for comparison with McFarland turbidity. From that suspension, $20 \mu \mathrm{L}$ was pipetted into the six tubes, except tube \#5, which was considered as a negative control. The tubes were incubated at $25^{\circ} \mathrm{C}$ for 14 days. The MIC is the lowest concentration of an antimicrobial agent that inhibited the visible growth of a microorganism [37,38].

\subsection{Determination of COX Inhibition}

The S. viticina EO inhibitory activity of human recombinant COX-2 and ovine COX-1 enzymes was assessed using a COX inhibitor screening method (Cayman Chemical, kit No.560131, Ann Arbor, MI, USA). The yellow color of the enzymatic reaction was evaluated using UV spectrophotometer in a Microplate Reader at a wavelength of $415 \mathrm{~nm}$. Cyclooxygenase inhibitory assay was performed for two concentrations of EO $(0.25$ and $0.5 \mu \mathrm{g} / \mathrm{mL})$ with celecoxib (a commercial NSAID marker). The anti-inflammatory activity of the tested $\mathrm{EO}$ was determined by calculating the percentage production inhibition of prostaglandin E2 (PGE2). The tested compounds concentration causing 50\% inhibition $\left(\mathrm{IC}_{50}\right)$ of the formation of prostaglandin PGE2 by COX1 and COX2 enzymes were determined from the curve of concentration inhibition response by regression analysis [39].

\subsection{Cell Culture and Cytotoxicity Assay}

The HeLa (cervical adenocarcinoma) and Colo-205 (colon) cancer cells were cultured in media (RPMI-1640) and supplemented with 10\% fetal bovine serum, 1\% Penicillin/Streptomycin antibiotics and $1 \%$ l-glutamine. Cells were grown in a humidified atmosphere with $5 \% \mathrm{CO}_{2}$ at $37^{\circ} \mathrm{C}$. Cells were seeded in 96-well plates $\left(2.6 \times 10^{4}\right.$ cells). After $48 \mathrm{hrs}$, the cells were incubated with EO at various concentrations for $24 \mathrm{~h}$. Cell viability was assessed by Cell-Tilter $96^{\circledR}$ Aqueous One Solution Cell Proliferation (MTS) Assay following the instructions of the manufacturer (Promega Corporation, Madison, WI, USA). At the end of the treatment, $20 \mu \mathrm{L}$ of MTS solution per $100 \mu \mathrm{L}$ of media was added to each well and incubated at $37^{\circ} \mathrm{C}$ for $2 \mathrm{~h}$ and finally, the absorbance was spectrophotometrically estimated at $490 \mathrm{~nm}[40]$.

\subsection{Statistical Examination}

All the data on $\alpha$-amylase, $\alpha$-glucosidase and porcine pancreatic enzymes inhibitory activity as well as on the antioxidant, COX inhibitory and cytotoxicity activities were the average of triplicate analyses. The outcomes were presented as means \pm standard deviation (SD). Statistical analysis was established employing GraphPad Prism software version 6.01 (GraphPad, San Diego, CA).

\section{Conclusions}

The GC-MS analysis revealed the presence of fifty-two compounds in the S. viticina EO, of which endo-borneol was the major component, followed by eucalyptol and epizonarene. The EO of S. viticina showed an ability to scavenge the free radical DPPH with an $\mathrm{IC}_{50}$ value of $19.95 \mu \mathrm{g} / \mathrm{mL}$ and displayed cytotoxic activity against colon and HeLa cancer cells at $0.5 \mathrm{mg} / \mathrm{mL}$ and $1.25 \mathrm{mg} / \mathrm{mL}$, respectively. It also showed very strong antimicrobial (against three Gram-positive, three Gram-negative bacteria and two fungi) effects, of which the strongest was against MRSA, with a MIC value of $0.039 \mathrm{mg} / \mathrm{mL}$. Moreover, the $S$. viticina EO showed high cyclooxygenase inhibitory activity against COX-1 and COX-2, with $\mathrm{IC}_{50}$ values of 0.25 and $0.5 \mu \mathrm{g} / \mathrm{mL}$, respectively, similar to those of the positive control (the NSAID etodolac). In addition, the EO showed potential in inhibiting the activity of $\alpha$-amylase ( $56.52 \%$ at 45.22 $\mu \mathrm{g} / \mathrm{mL})$ and of $\alpha$-glucosidase $(69.82 \%$ at $63.09 \mu \mathrm{g} / \mathrm{mL})$. Briefly, S. viticina EO contains pharmacologically active molecules which could be further validated and explored clinically for their therapeutic potential and for the development and design of new natural therapeutic preparations.

Supplementary Materials: The following are available online, Figure S1. GC-MS chromatogram of S. viticina EO, Figure S2. DPPH Inhibition \% by Trolox (positive control) and S. viticina EO, Figure S3. The $\alpha$-amylase inhibitory 
potential by Acarbose (positive control) and S. viticina EO, Figure S4. The $\alpha$-glucosidase inhibitory potential by Acarbose (positive control) and S. viticina EO, Figure S5. Lipase enzyme inhibitory activity by S. viticina EO and Orlistat (positive control).

Author Contributions: Conceptualization, N.J. and N.A.-M.; methodology, N.J. and N.A.-M.; software, N.J. and N.A.-M.; validation, N.J. and N.A.-M.; formal analysis, N.J. and N.A.-M.; investigation, N.J. and N.A.-M.; resources, N.J. and N.A.-M.; data curation, N.J. and N.A.-M.; writing-original draft preparation, N.J.; writing-review and editing, N.A.-M.; visualization, N.J. and N.A.-M; supervision, N.J. and N.A.-M; project administration, N.J. and N.A.-M.

Funding: This research received no external funding.

Acknowledgments: The authors wish to thank An-Najah National University for its support to carry out this work

Conflicts of Interest: The authors declare that there are no conflicts of interest.

\section{References}

1. Dimitrios, B. Sources of natural phenolic antioxidants. Trends Food Sci. Technol. 2006, 17, 505-512. [CrossRef]

2. Locatelli, M. Anthraquinones: Analytical techniques as a novel tool to investigate on the triggering of biological targets. Curr. Drug Targets 2011, 12, 366-380. [CrossRef]

3. Locatelli, M.; Epifano, F.; Genovese, S.; Carlucci, G.; Končić, M.Z.; Kosalec, I.; Kremer, D. Anthraquinone profile, antioxidant and antimicrobial properties of bark extracts of rhamnus catharticus and r. Orbiculatus. Nat. Prod. Commun. 2011, 6, 1934578X1100600917. [CrossRef]

4. Rahimi Khoigani, S.; Rajaei, A.; Goli, S.A.H. Evaluation of antioxidant activity, total phenolics, total flavonoids and lc-ms/ms characterisation of phenolic constituents in Stachys lavandulifolia. Nat Prod Res 2017, 31, 355-358. [CrossRef] [PubMed]

5. Heymach, J.; Krilov, L.; Alberg, A.; Baxter, N.; Chang, S.M.; Corcoran, R.B.; Dale, W.; DeMichele, A.; Magid Diefenbach, C.S.; Dreicer, R. Clinical cancer advances 2018: Annual report on progress against cancer from the american society of clinical oncology. J. Clin. Oncol. 2018, 36, 1020-1044. [CrossRef] [PubMed]

6. Seca, A.; Pinto, D. Plant secondary metabolites as anticancer agents: Successes in clinical trials and therapeutic application. Int. J. Mol. Sci. 2018, 19, 263. [CrossRef] [PubMed]

7. Chouhan, S.; Sharma, K.; Guleria, S. Antimicrobial activity of some essential oils-present status and future perspectives. Medicines 2017, 4, 58. [CrossRef]

8. Locatelli, M.; Genovese, S.; Carlucci, G.; Kremer, D.; Randic, M.; Epifano, F. Development and application of high-performance liquid chromatography for the study of two new oxyprenylated anthraquinones produced by Rhamnus species. J. Chromatogr. A 2012, 1225, 113-120. [CrossRef]

9. Skaltsa, H.D.; Demetzos, C.; Lazari, D.; Sokovic, M. Essential oil analysis and antimicrobial activity of eight Stachys species from greece. Phytochemistry 2003, 64, 743-752. [CrossRef]

10. Goren, A.C. Use of Stachys species (mountain tea) as herbal tea and food. Rec. Nat. Prod. 2014, 8, 71-82.

11. Tundis, R.; Peruzzi, L.; Menichini, F. Phytochemical and biological studies of Stachys species in relation to chemotaxonomy: A review. Phytochemistry 2014, 102, 7-39. [CrossRef] [PubMed]

12. Goren, A.C.; Piozzi, F.; Akcicek, E.; Kılıç, T.; Çarıkçı, S.; Mozioğlu, E.; Setzer, W.N. Essential oil composition of twenty-two Stachys species (mountain tea) and their biological activities. Phytochem. Lett. 2011, 4, 448-453. [CrossRef]

13. Wei, J.; Zhang, X.-Y.; Deng, S.; Cao, L.; Xue, Q.-H.; Gao, J.-M. A-glucosidase inhibitors and phytotoxins from Streptomyces xanthophaeus. Nat. Prod. Res. 2017, 31, 2062-2066. [CrossRef] [PubMed]

14. Loizzo, M.; Saab, A.; Statti, G.; Menichini, F. Composition and $\alpha$-amylase inhibitory effect of essential oils from Cedrus libani. Fitoterapia 2007, 78, 323-326. [CrossRef] [PubMed]

15. Ma, L.; Lin, Q.; Lei, D.; Liu, S.; Wang, X.; Zhao, Y. Alpha-glucosidase inhibitory activities of essential oils extracted from three chinese herbal medicines. Chem. Eng. Trans. 2018, 64, 61-66.

16. Dang, N.H.; Nhung, P.H.; Anh, M.; Thi, B.; Thuy, T.; Thi, D.; Minh, C.V.; Dat, N.T. Chemical composition and $\alpha$-glucosidase inhibitory activity of vietnamese citrus peels essential oils. J. Chem. 2016, 2016. [CrossRef]

17. Oboh, G.; Ademosun, A.O.; Odubanjo, O.V.; Akinbola, I.A. Antioxidative properties and inhibition of key enzymes relevant to type-2 diabetes and hypertension by essential oils from black pepper. Adv. Pharmacol. Sci. 2013, 2013, 215-219. [CrossRef] 
18. Salameh, N.; Shraim, N.; Jaradat, N. Chemical composition and enzymatic screening of Micromeria fruticosa serpyllifolia volatile oils collected from three different regions of west bank, palestine. BioMed Res. Int. 2018, 2018. [CrossRef]

19. Zheng, C.-D.; Li, G.; Li, H.-Q.; Xu, X.-J.; Gao, J.-M.; Zhang, A.-L. DPPH-scavenging activities and structure-activity relationships of phenolic compounds. Nat. Prod. Commun. 2010, 5, 1934578X1000501112. [CrossRef]

20. Kukić, J.; Petrović, S.; Niketić, M. Antioxidant activity of four endemic Stachys taxa. Biol. Pharm. Bull. 2006, 29, 725-729. [CrossRef]

21. Ebrahimabadi, A.H.; Ebrahimabadi, E.H.; Djafari-Bidgoli, Z.; Kashi, F.J.; Mazoochi, A.; Batooli, H. Composition and antioxidant and antimicrobial activity of the essential oil and extracts of Stachys inflata benth from iran. Food Chem. 2010, 119, 452-458. [CrossRef]

22. Conforti, F.; Menichini, F.; Formisano, C.; Rigano, D.; Senatore, F.; Arnold, N.A.; Piozzi, F. Comparative chemical composition, free radical-scavenging and cytotoxic properties of essential oils of six Stachys species from different regions of the mediterranean area. Food Chem. 2009, 116, 898-905. [CrossRef]

23. Taylor, J.; Van Staden, J. Cox-1 inhibitory activity in extracts from Eucomis l'herit. Species. J. Ethnopharmacol. 2001, 75, 257-265. [CrossRef]

24. Xiao, J.; Zhang, Q.; Gao, Y.-Q.; Tang, J.-J.; Zhang, A.-L.; Gao, J.-M. Secondary metabolites from the Endophytic botryosphaeria dothidea of melia azedarach and their antifungal, antibacterial, antioxidant, and cytotoxic activities. J. Agric. Food Chem. 2014, 62, 3584-3590. [CrossRef]

25. Gerets, H.; Hanon, E.; Cornet, M.; Dhalluin, S.; Depelchin, O.; Canning, M.; Atienzar, F. Selection of cytotoxicity markers for the screening of new chemical entities in a pharmaceutical context: A preliminary study using a multiplexing approach. Toxicol. Vitr. 2009, 23, 319-332. [CrossRef]

26. Jaradat, N.; Al-lahham, S.; Abualhasan, M.N.; Bakri, A.; Zaide, H.; Hammad, J.; Hussein, F.; Issa, L.; Mousa, A.; Speih, R. Chemical constituents, antioxidant, cyclooxygenase inhibitor, and cytotoxic activities of Teucrium pruinosum boiss. Essential oil. BioMed Res. Int. 2018, 2018. [CrossRef]

27. Shehadeh, M.; Jaradat, N.; Al-Masri, M. Rapid, cost-effective and organic solvent-free production of biologically active essential oil from mediterranean wild origanum syriacum. Saudi Pharm. J. 2019, 27, 612-618. [CrossRef]

28. Jaradat, N.A.; Zaid, A.N.; Abuzant, A.; Shawahna, R. Investigation the efficiency of various methods of volatile oil extraction from Trichodesma africanum and their impact on the antioxidant and antimicrobial activities. J. Intercult. Ethnopharmacol. 2016, 5, 250-256. [CrossRef]

29. Vinaixa, M.; Schymanski, E.L.; Neumann, S.; Navarro, M.; Salek, R.M.; Yanes, O. Mass spectral databases for LC/MS-and GC/MS-based metabolomics: State of the field and future prospects. TrAC Trends Anal. Chem. 2016, 78, 23-35. [CrossRef]

30. Wei, X.; Koo, I.; Kim, S.; Zhang, X. Compound identification in GC-MS by simultaneously evaluating the mass spectrum and retention index. Analyst 2014, 139, 2507-2514. [CrossRef]

31. Serfling, A.; Wohlrab, J.; Deising, H.B. Treatment of a clinically relevant plant-pathogenic fungus with an agricultural azole causes cross-resistance to medical azoles and potentiates caspofungin efficacy. Antimicrob. Agents Chemother. 2007, 51, 3672-3676. [CrossRef] [PubMed]

32. Zheng, C.-D.; Duan, Y.-Q.; Gao, J.-M.; Ruan, Z.-G. Screening for anti-lipase properties of 37 traditional chinese medicinal herbs. J. Chin. Med Assoc. 2010, 73, 319-324. [CrossRef]

33. Nyambe-Silavwe, H.; Villa-Rodriguez, J.A.; Ifie, I.; Holmes, M.; Aydin, E.; Jensen, J.M.; Williamson, G. Inhibition of human $\alpha$-amylase by dietary polyphenols. J. Funct. Foods 2015, 19, 723-732. [CrossRef]

34. Ademiluyi, A.O.; Oboh, G. Soybean phenolic-rich extracts inhibit key-enzymes linked to type 2 diabetes ( $\alpha$-amylase and $\alpha$-glucosidase) and hypertension (angiotensin i converting enzyme) in vitro. Exp. Toxicol. Pathol. 2013, 65, 305-309. [CrossRef] [PubMed]

35. Jaradat, N.A.; Al-lahham, S.; Zaid, A.N.; Hussein, F.; Issa, L.; Abualhasan, M.N.; Hawash, M.; Yahya, A.; Shehadi, O.; Omair, R. Carlina curetum plant phytoconstituents, enzymes inhibitory and cytotoxic activity on cervical epithelial carcinoma and colon cancer cell lines. Eur. J. Integr. Med. 2019, 30, 93-100. [CrossRef]

36. Jaradat, N.A.; Shawahna, R.; Hussein, F.; Al-Lahham, S. Analysis of the antioxidant potential in aerial parts of Trigonella arabica and Trigonella berythea grown widely in palestine: A comparative study. Eur. J. Integr. Med. 2016, 8, 623-630. [CrossRef]

37. Tille, P. Bailey E Scott's Diagnostic Microbiology e-Book; Elsevier Health Sciences: Berlin, Germany. 
38. Wikler, M.A. Performance Standards for Antimicrobial Susceptibility Testing: Seventeenth Informational Supplement; Clinical and Laboratory Standards Institute: Wayne, PA, USA, 2007.

39. Murias, M.; Handler, N.; Erker, T.; Pleban, K.; Ecker, G.; Saiko, P.; Szekeres, T.; Jäger, W. Resveratrol analogues as selective cyclooxygenase- 2 inhibitors: Synthesis and structure-activity relationship. Bioorganic Med. Chem. 2004, 12, 5571-5578. [CrossRef]

40. Mosmann, T. Rapid colorimetric assay for cellular growth and survival: Application to proliferation and cytotoxicity assays. J. Immunol. Methods 1983, 65, 55-63. [CrossRef]

C 2019 by the authors. Licensee MDPI, Basel, Switzerland. This article is an open access article distributed under the terms and conditions of the Creative Commons Attribution (CC BY) license (http://creativecommons.org/licenses/by/4.0/). 